\title{
Studies on saline water intrusion in the coastal stretch of Kadalundi river basin, Malappuram district, Kerala using visual MODFLOW - A case study.
}

Dr. Sajeena S ( $\square$ sajeenahakkim@gmail.com )

Kerala Agricultural University

\section{Swathy P.S}

Kerala Agricultural University

Abdul Hakkim V. M.

Professor (SWE), Dept. of Agricultural Engineering, College of Agriculture, Padanakkad, Kasargod.

\section{Research Article}

Keywords: Visual MODFLOW, MT3D software, saline water intrusion, contaminant transport, transient flow

Posted Date: June 10th, 2020

DOI: https://doi.org/10.21203/rs.3.rs-34501/v1

License: (c) (1) This work is licensed under a Creative Commons Attribution 4.0 International License.

Read Full License 


\section{Abstract}

The study on simulation of sea water intrusion into the coastal aquifers using Visual MODFLOW was conducted on coastal stretch of Tanur, Tirurangadi and Parappanagadi blocks of the Kadalundi river basin and this area comprises of about $130 \mathrm{~km}^{2}$ drainage area. The base map of the study area was imported into the model in BMP format and divided into 40 columns and 40 rows ( 1600 cells). Water level and water quality data of observation wells maintainedby Ground Water Department, Govt. of Kerala was used as input to the model. Secondary data on hydrogeological parameters and aquifer properties were also used as the input parameters of the model. In this study, Visual MODFLOW 2.8.1 integrated with MT3D software was used for groundwater modelling and contaminant transport modelling. It was observed that there is a chance of saline water intrusion in the coastal stretch of study area. There are chances of saline water intrusion to a lateral distance of $0.5 \mathrm{~km}$ to $1.9 \mathrm{~km}$ from the coast which extents 3.2 to $4.5 \mathrm{~km}$ along the coast from northern boundary of Kadalundi river basin. Coconut retting, lime shelling and sand mining activities in the river basin were a potential source of pollution and contaminant transport. Development of small industries, construction of buildings and agricultural activities in the coastal stretch of river basin necessitated increased rate of pumping of ground water. This increased pumping of ground water leads to the entry of salt water into the fresh water aquifer formations. Global warming and sea level rise are also threatening problems in the current climate change scenario which is also a reason for saline water intrusion in to the coastal fresh water aquifers. Groundwater replenishment through natural and artificial recharge and sustainable development activities in the area are the main countermeasures to overcome this problem.

\section{Introduction}

Water is a vital natural resource and the entire living organisms in the world depend on this natural commodity. Human civilization existed around water from ancient centauries for drinking, food production and transport, recreation as well as inspiration. More than one third of the water used by human beings comes from groundwater. Groundwater is one of the most valuable natural resource. Its availability as well as quality is very critical to existence of life. The ever increasing demand of groundwater for drinking, agriculture, and industrial purposes along with ever increasing threats from the contamination, puts the groundwater at an important juncture-one that necessitates by each and every one of us. Groundwater is the water present beneath the earth surface in the soil pore spaces and in the fractures of the rock formations. In coastal areas, shortage of fresh water supply will cause salt water intrusion. Salt water intrusion refers to the process by which sea water infiltrates to the coastal ground water systems, thus mixing with local fresh water supply. (Barlow, 2010). Malappuram is the most densely populated district in Kerala. Coastal regions of Tanur, Tirurangadi and Parappanangadi blocks of kadalundi river basin in Malappuram district were taken as the study area. The study was done using the model Visual MODFLOW. Visual MODFLOW is a groundwater model developed by U S geological survey. Ground water models are the simplification of complex reality and they are very useful tool for 
investigating groundwater problems. Model planning conceptualization, model design, construction, calibration, validation and prediction are the different steps involved in modeling process. (Merz, 2013). Direction of flow, aquifer geometry, heterogeneity or anisotropy of sediments or bed rock within the aquifer, contaminant transport mechanisms and chemical reactions are certain simplifying assumptions which ground water model is based. (Sajeena,2015). The study has been carried out in the Kadalundi river basin, in Malappuram district, Kerala, India due to water quality problems in the river basin. Water quality problems in Kadalundi river basin was mainly associated with $\mathrm{pH}$, conductivity, colour, turbidity, chloride, hardness, sulphate, iron, dissolved oxygen and fecal contamination.( Harikumar et al, 2010).

\section{Materials And Methods}

Groundwater availability and quality are very critical to the existence of life. In order to cope up with the increasing demand of ground water, its proper understanding is necessary. The objective of present research was to simulate the salt water intrusion in to the coastal aquifers of Kadalundy river basin in Malappuram district using the ground water model Visual MODLOW. Visual MODFLOW version 2.8.1, which is developed by Waterloo Hydrogeologocal Inc was used for the study. A numeric engine in Visual MODFLOW named MT3D was used for contaminant transport modeling. Coastal stretch of Tanur, Tirurangadi and Parappanangadi blocks of Kadalundi river basin has taken as the total area of study which comprise of 130 sq. km drainage area (Fig. 1). The study area was digitized using Google Earth software for easiness. Coastal alluvium, riverine alluvium and laterite soil are the main soil types present in the area. In this study Visual MODFLOW model was developed and calibrated using 7 years data (2000 to 2006) and validated using 3 years data (2007 to 2009). After validation the model was used to predict the ground water scenario and sea water intrusion of next 10 years. Visual MODFLOW supports the use of base maps in all modules of the program. Raster map of kadalundi river basin obtained from CWRDM was overlaid in to Google Earth software and study area was digitized to prepare the base map. Base map was converted in to BMP format. Base map was imported in to model screen and it was geo referenced using geo referencing option in Visual MODFLOW software. The conceptual model for the study area was developed based on the topo sheet of the area, well logs at 6 sites and the data obtained from

Central Ground Water Department and previous literatures. The aquifer system of the study area for modelling purpose was assumed homogenous, isotropic, single layer and unconfined aquifer. More than 80 per cent of the ground water extraction takes place from the first aquifer. The rainfall is the main source of aquifer recharge on the study area. The study area was discretized by dividing it in to 40 rows and 40 columns with grid spacing $500 \mathrm{~m} \times 500 \mathrm{~m}$. Thus the study area was discretized in to 1600 cells and the cells outside the boundary of the study area were made inactive. After completing the uploading of all input data, the model was run for transient state conditions. WHS solver was selected. The WHS solver act as two tier system to a solution at one step. Transient run was done for 10 years stress period with data using 2000 to 2009 . The simulated data were compared with observed data. 


\section{Results And Discussions}

The hydraulic conductivity values, boundary conditions, water levels, specific storage, specific yield, initial heads and recharge data were used for transient state calibration. The transient state calibration was done for the period from the year 2000 to 2006 (2557 days). The storage coefficient values were varied iteratively so that a reasonably good match was obtained between calculated and observed values. The hydraulic property values obtained after transient state calibration are shown in Table 1. The computed and observed water level graphs for selected observation wells after calibration is shown in Fig. 2. From the figure, it could be seen that calculated head values are on par with observed values. The graph lies in 95 per cent confidence level. This is a clear indication of proper model development with relevant water table data.

Table 1. Hydraulic properties of the layer after calibration

\begin{tabular}{|lll|}
\hline SI.NO & Model Properties & $\begin{array}{l}\text { Layer } 1 \\
\text { Laterite }\end{array}$ \\
\hline 1 & Hydraulic conductivity in longitudinal direction $\mathrm{K}_{\mathrm{x}}, \mathrm{md}^{-1}$ & 55 \\
\hline 2 & Hydraulic conductivity in lateral direction $\mathrm{K}_{\mathrm{y}}, \mathrm{md}^{-1}$ & 55 \\
\hline 3 & Hydraulic conductivity in vertical direction $\mathrm{K}_{\mathrm{z}}, \mathrm{md}^{-1}$ & 3 \\
\hline 4 & Specific storage $\mathrm{S}_{\mathrm{s}}, \mathrm{m}^{-1}$ & 0.0005 \\
\hline 5 & Specific Yield $\mathrm{S}_{\mathrm{y}}, \%$ & 20 \\
\hline 6 & Effective porosity, $\%$ & 35 \\
\hline 7 & Total porosity, $\%$ & 40 \\
\hline
\end{tabular}

Computed water table contour map of the study area obtained from the model is shown in Fig.3. From the figure, it could be seen that in coastal region the water table elevation was very low ranging from zero to $6 \mathrm{~m}$. At the extreme west side, it is zero because of Arabian Sea as boundary. Water table in the entire study area ranges from -6.2 to $9.5 \mathrm{~m}$ (green to red shade). Tirurangadi-Chemmad area has highest water table (red shade).

The velocity vector of the study area is given in the Fig. 4. At the southern coastal side of the study area, the direction of flow was towards Arabian Sea. At Tanur block region the flow was north easterly. And a chance of saline water intrusion was present in the area where the Kadalundi River joins to Arabian Sea and there was a fluctuation in the flow towards Arabian Sea. The flow direction was towards east which 
means towards inland in Parappanangadi, Chettipadi, Ariyallur and Vallikkunnu area which indicated a chance of saline water intrusion, which was coincides with the result of water table contour map.

After calibration, it needs to be validated the model which is accomplished by testing the model with data which are not used for the calibration. The validation is done for the period from 2007 to 2009 (3653 days). Observed head Vs calculated head graph is shown in Fig. 5. From the figure, it could be seen that the values are in 95 per cent confidence interval.

Prediction was done from 2010 to 2019 (3653) Fig. 6 represent the water table contour map after increasing the pumping rate by 5,10 and 15 per cent respectively. There is a decline in water table in the coastal stretch. Thus a hydraulic gradient is developed which will lead the movement of saline water to the coastal fresh water aquifers. Computed head Vs time graph after prediction is shown in Fig. 48 to Fig. 51. From the figure, it could be seen that water level was decreasing when the pumping rate was increased up to 15 per cent. In between the days 3653 and 4653, there indicated a sudden decrease in the elevation of water table. After 5653 days, water table elevation line becomes constant which may be because the water table reached the bed rock region and these results were in agreement with the finding of Sajeena (2015).

\section{Contaminant Transport Modelling}

Salt water intrusion study was carried out using visual MODFLOW with MT3D and this provided the observed concentration Vs calculated concentration graph, concentration Vs time graph and concentration contour map as output. Computed Vs observed concentration map for the selected four observation wells (wells of Tanur, Tirurangadi and Parappanangadi blocks) are shown in Fig. 7. It could be seen that computed and observed values are on par at 95 per cent confidence interval. Concentration contour map of the study area obtained from the model after calibration is shown in Fig. 8. From this figure, it could be seen that intrusion was present up to $3.2 \mathrm{~km}$ along the coastal stretch from the northern boundary of the area (Kadalundi estuary region) which extended from 0.5 to $1.2 \mathrm{~km}$ laterally from the coast.

Calibration values are taken in to consideration for validation of the model. The model was validated with the water quality data of the period from 2007 to 2009. Scatter plots for computed Vs observed concentration for selected observation wells are shown in Fig. 9 and it could be seen that the Root Mean Square Error (RMSE) value for almost all the wells during validation are reasonably low and are within the acceptable limits. Concentration contour map after validation is shown in Fig. 10 and it was observed that there is a chance of saline water intrusion in to the coasts of Parappanangadi and Cheeramangalam area which is extended to a distance of $1 \mathrm{~km}$ from the point where the sea water presence after calibration.

Validated values of calculated and observed heads and concentrations are shown in Table 2 and Table 3. From these tables, it is evident that normalized RMS is less than 10. The model values are matching with 
observed values. Hence the model is ready for prediction.

The validated model was run for predicting the trend of saline water intrusion for next 10 years (3653 days) by assuming increase of pumping rate by 5,10 and 15 per cent. Fig. 11 showed that the predicted concentration contour map for next 10 years by increasing the pumping rate by 5, 10 and 15 per cent and it could be observed that, if the pumping rate is increased from 5 per cent to 10 per cent, there is a clear increase of saline water intrusion in the coastal stretch of the river basin. There is no change in saline water intrusion when pumping rate is increased from 10 per cent to 15 per cent which indicate that water table reached the bed rock. By 2019 vertical extent of saline water increases which ranges from 3.2 to 4.5 $\mathrm{km}$ along the coast from the northern boundary (Kadalundi estuary region) which extends laterally from 1 $\mathrm{km}$ to $1.9 \mathrm{~km}$ from the coast.

Table.2. Validated values of observed and calculated head

\begin{tabular}{|lllll|}
\hline SL.NO & Well Name & Observed Head & Calculated Head & RMSE value \\
\hline 1 & BW 189 & 38.22 & 38.24 & 0.021 \\
\hline 2 & BW 190 & 0.69 & 0.76 & 0.072 \\
\hline 3 & OW 5A & 0.43 & 3.41 & 2.98 \\
\hline 4 & OW 6A & 64.22 & 68.29 & 4.07 \\
\hline 5 & OW 178 & -5.64 & -5.31 & 0.331 \\
\hline 6 & OW 35 & -3.70 & -1.50 & 2.20 \\
\hline
\end{tabular}

\begin{tabular}{|lllll|}
\hline SL. NO & Well name & Observed value & Calculated value & RMSE value \\
\hline 1 & BW 190 & 20.51 & 20.66 & 0.15 \\
\hline 2 & BW 189 & 20.66 & 20.66 & 0.001 \\
\hline 3 & OW 5A & 20.55 & 20.66 & 0.11 \\
\hline 4 & OW 6A & 16.25 & 16.15 & 0.97 \\
\hline
\end{tabular}

Table. 3. Validated values of observed and calculated head

From all the above given results it can be concluded that there is a clear indication of saline water intrusion in the coastal stretch of the Kadalundi river basin due to drastic increase of pumping rates. The 
main objective of the study was to simulate the saline water flow condition in the river basin and to predict the advancement of saline water into the coast. The graph of observed values Vs calculated values remain around 95 per cent confidence level, which indicate that calculated and observed values are almost same. In the head Vs time graph and concentration Vs time graph, the calculated and observed lines remain closer. These two parameters indicate that simulation of the model was done in the right way. Concentration contour map after increasing the pumping rate by 5,10 and 15 per cent help to predict the advancement of saline water in to the coast. Analysis of predicted contour maps indicate that by 2019 saline water will intrude into the land about 1 to $1.9 \mathrm{~km}$ from the coastal line.

\section{Conclusions}

Development of small industries, construction of buildings and agriculture activities in the coastal stretch of river basin necessitated increased rate of pumping of ground water. This increased pumping of ground water lead to the entry of salt water in to the fresh water aquifer formations. Global warming and sea level rise are also threatening problems in the current climate change scenario which is also a reason for saline water intrusion in to the coastal fresh water aquifers. Ground water replenishment through natural and artificial recharge and sustainable development activities in the area are the main countermeasures to overcome this problem.

\section{Declarations}

Competing interests: The authors declare no competing interests.

\section{References}

1. Barlow, P. M. and Reichard, E. G. 2010. Salt water intrusion in coastal regions of North America. J. 18:247-260.

2. Harikumar, P.S. and Kokkal, K. 2010. Kadalundi river basin environmental monitoring programme on water quality. Centre for Water Resour.Dev. and Manag.85-123.

3. Merz, S. K. 2002. Australian groundwater modelling guidelines: companion to the guidelines, National Water Commission, Canberra, 31p. Available: http//nwc.gov.au/_data/assets/pdf_file/0018/35091/companion-to-modelling-guidelines.pdf [Jul 2013].

4. Rajamanickam, R. and Nagan, S. 2010. Groundwater quality modelling of Amaravathi river basin of Karur district, Tamil Nadu, using Visual Modflow. J. Environ. Sci. 1(1):91-105.

5. Rejani, R., Jha, M. K., Panda, S. N. and Mull, R. 2008. Simulation modelling for efficient groundwater management in Balasore coastal basin, India. Water Resour. Manag. 22:23-50.

6. Sajeena, S. 2015. Ground water resources modelling of a watershed using MODFLOW. (Ag. Eng.) thesis, Kelappaji College of Agricultural Engineering and Technology, Tavanur, 179p. 
Figures

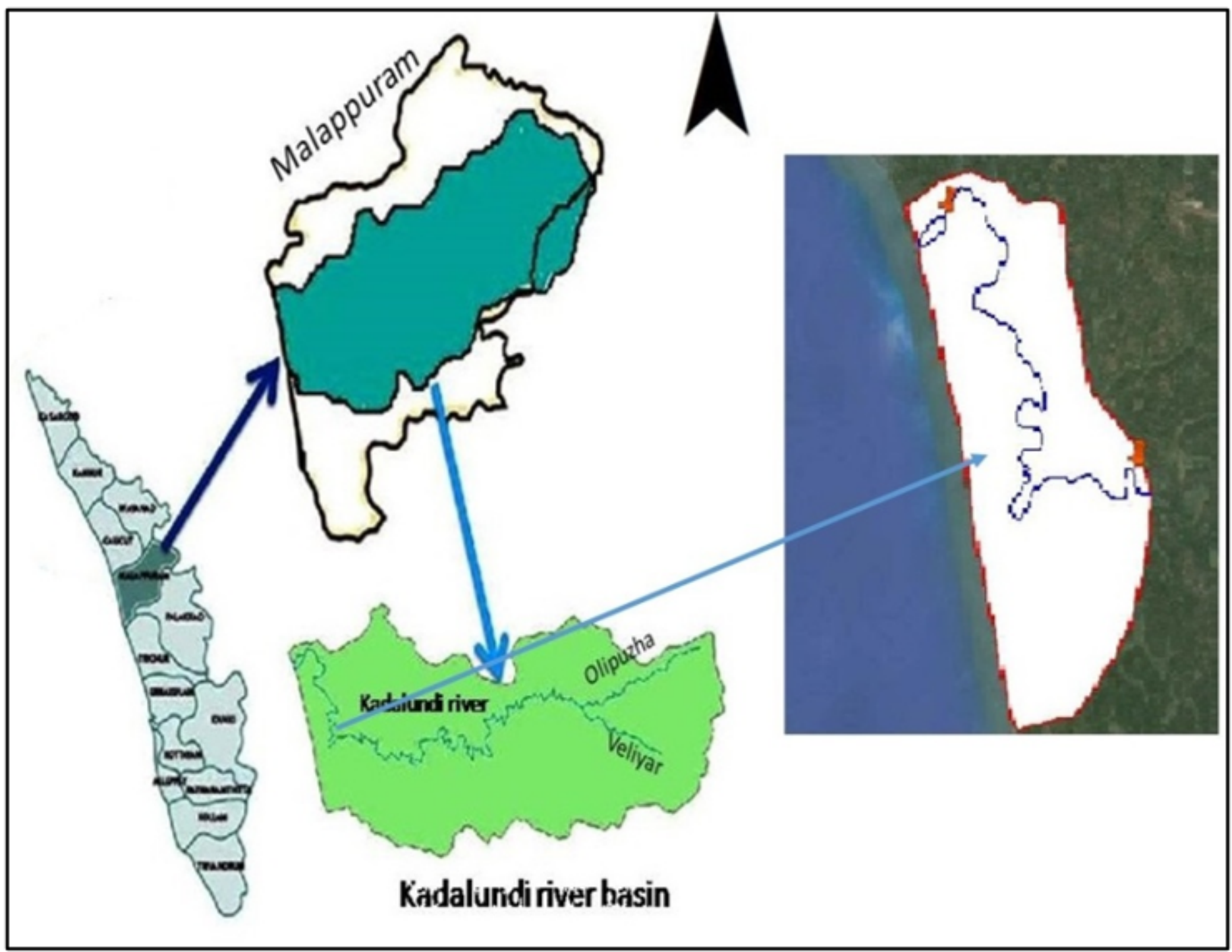

Figure 1

Location map of the study area 


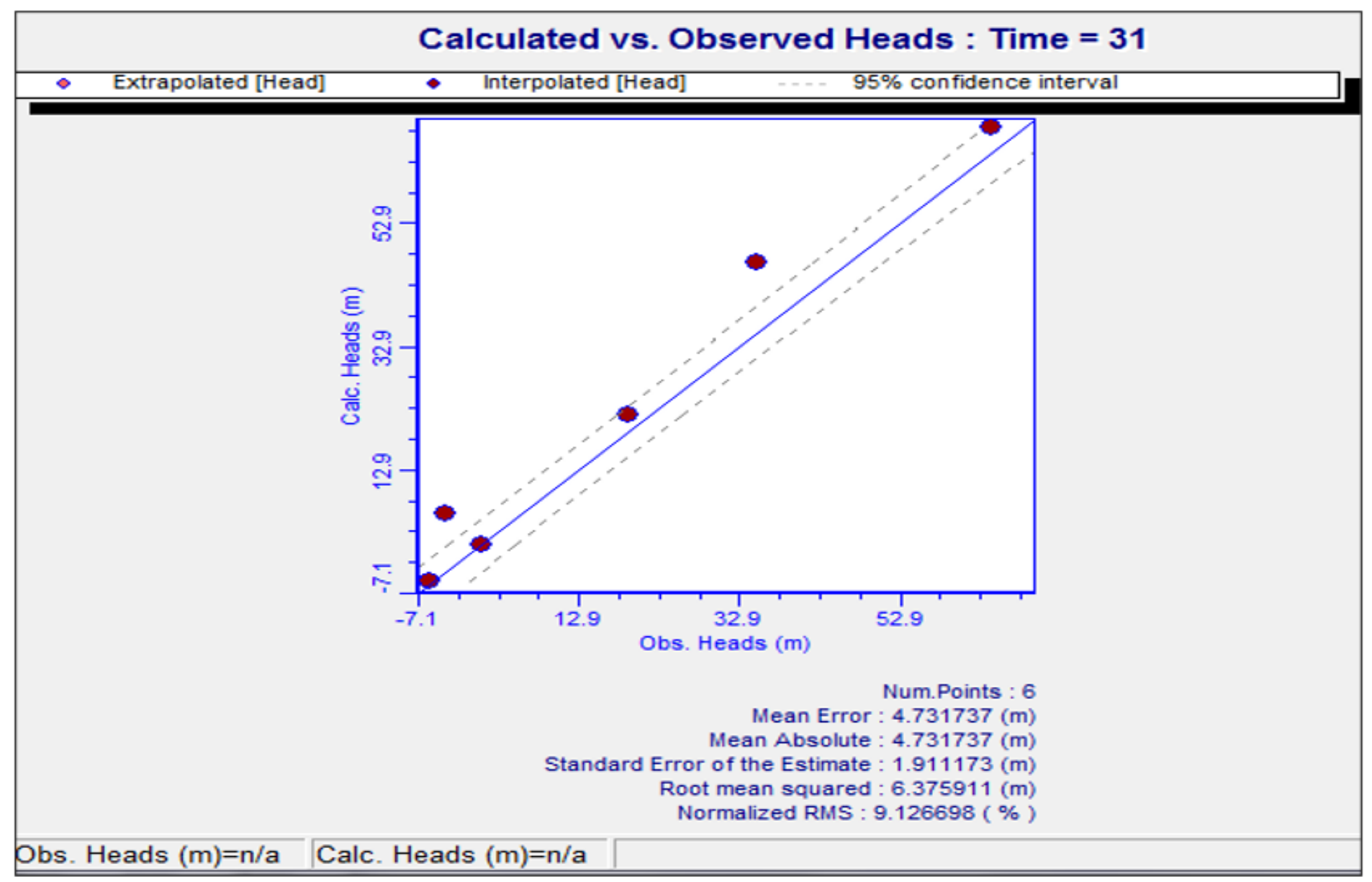

Figure 2

Model computed Vs observed water level after calibration 


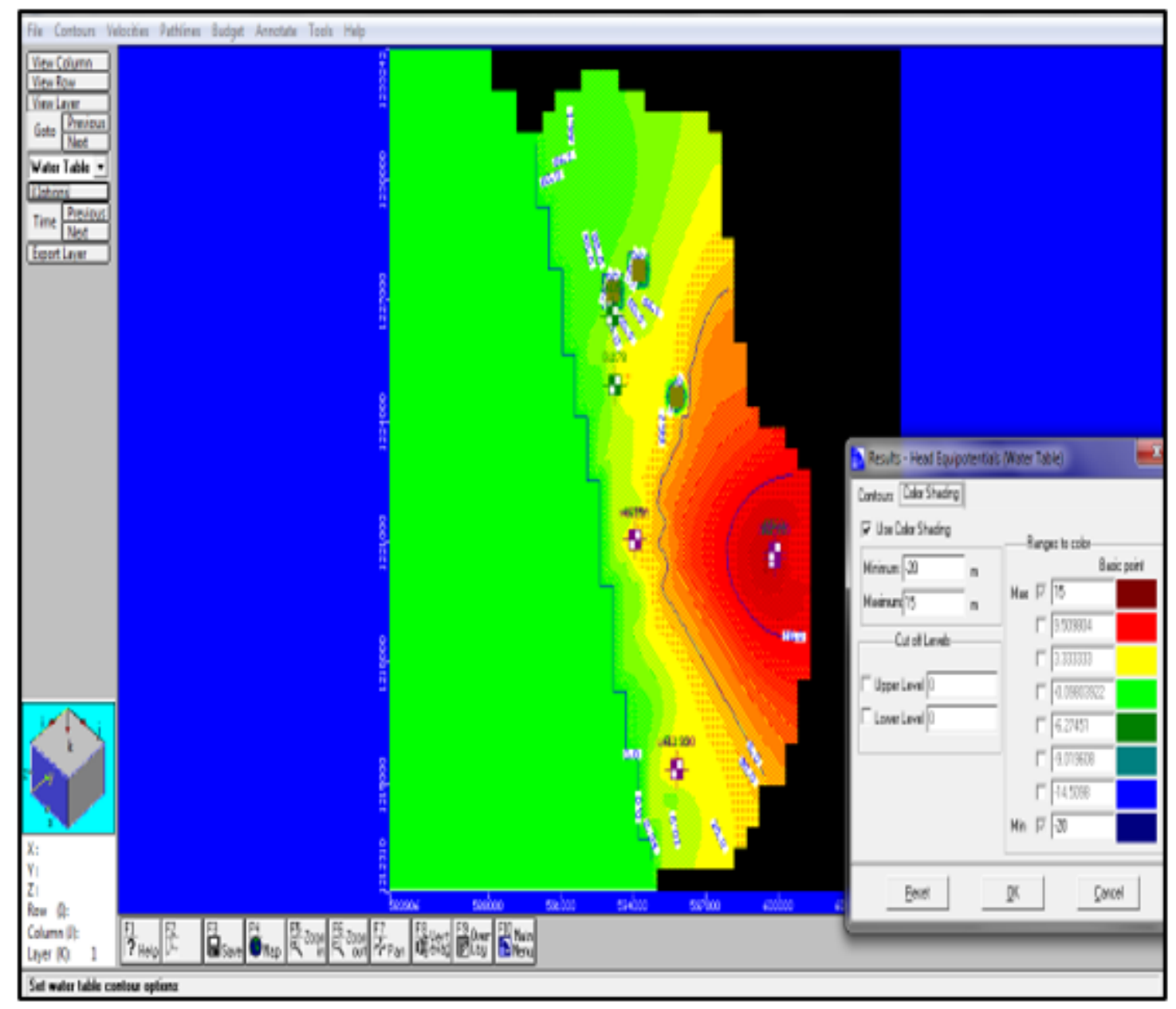

Figure 3

Computed water table contour map in the mode 


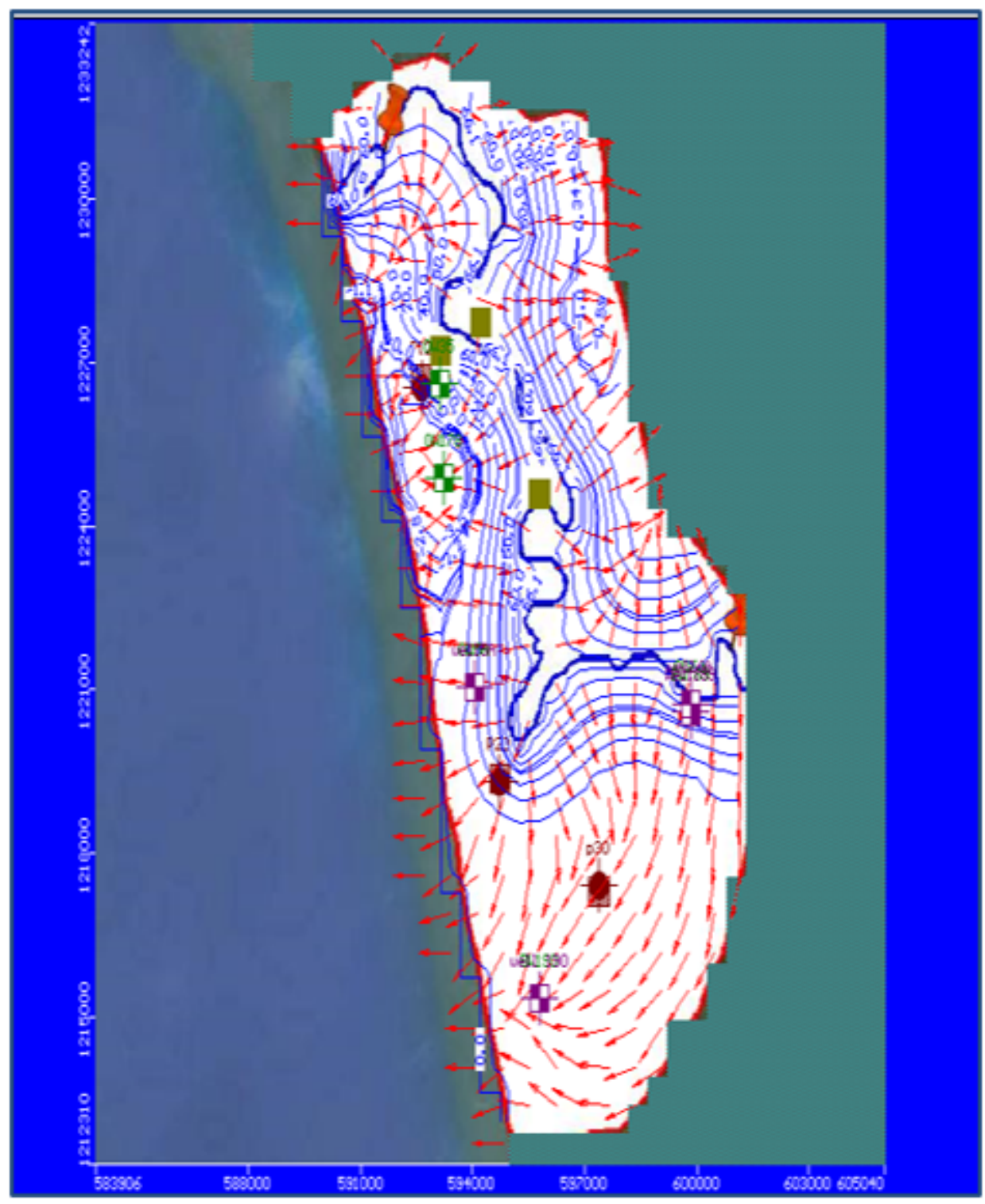

Figure 4

Velocity vectors of the study area after calibration 


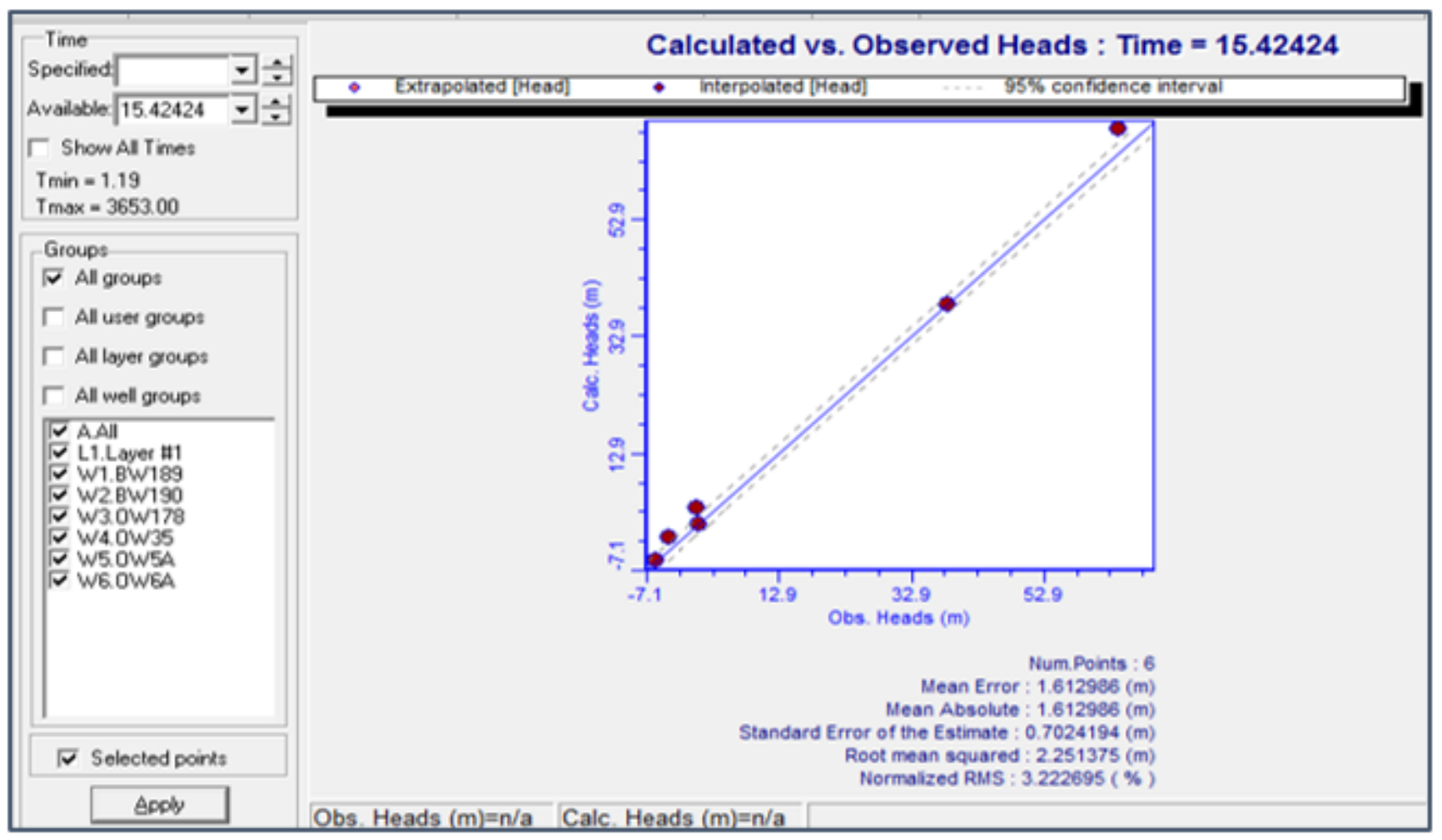

Figure 5

Model computed Vs observed water level after validation

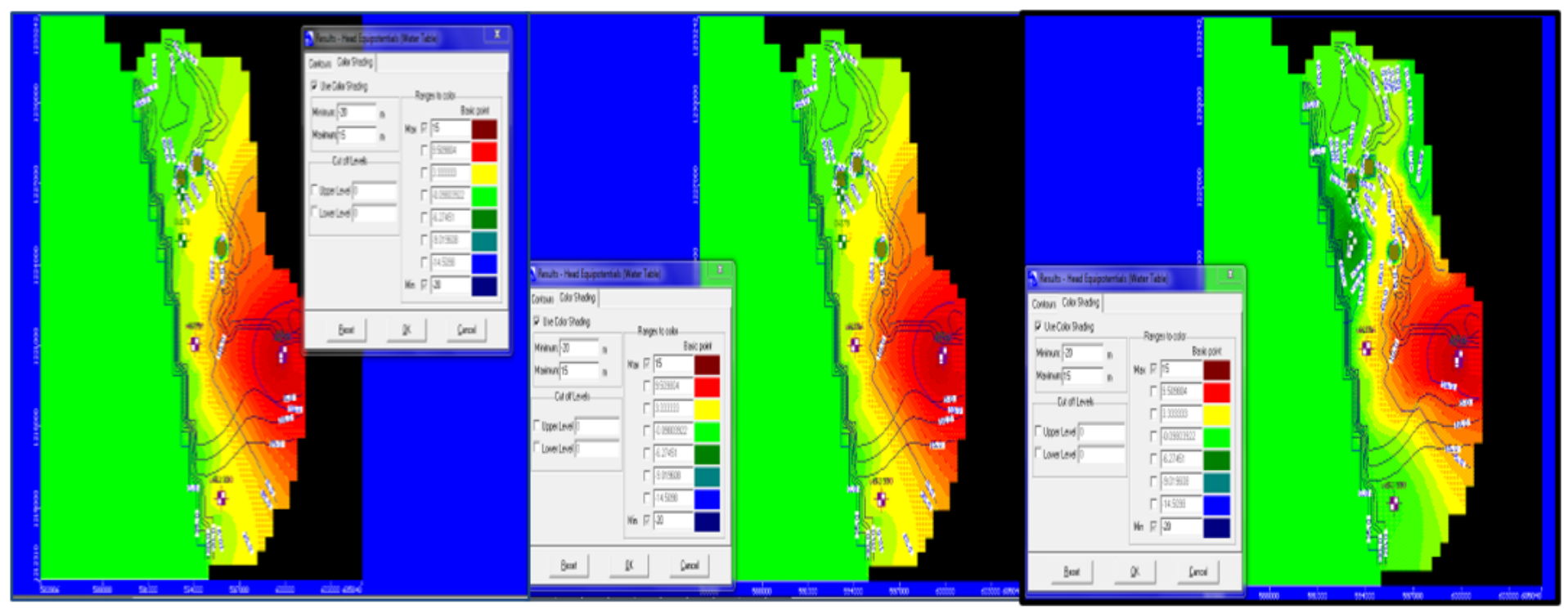

Figure 6

Predicted water table contour map after increasing the pumping rate 


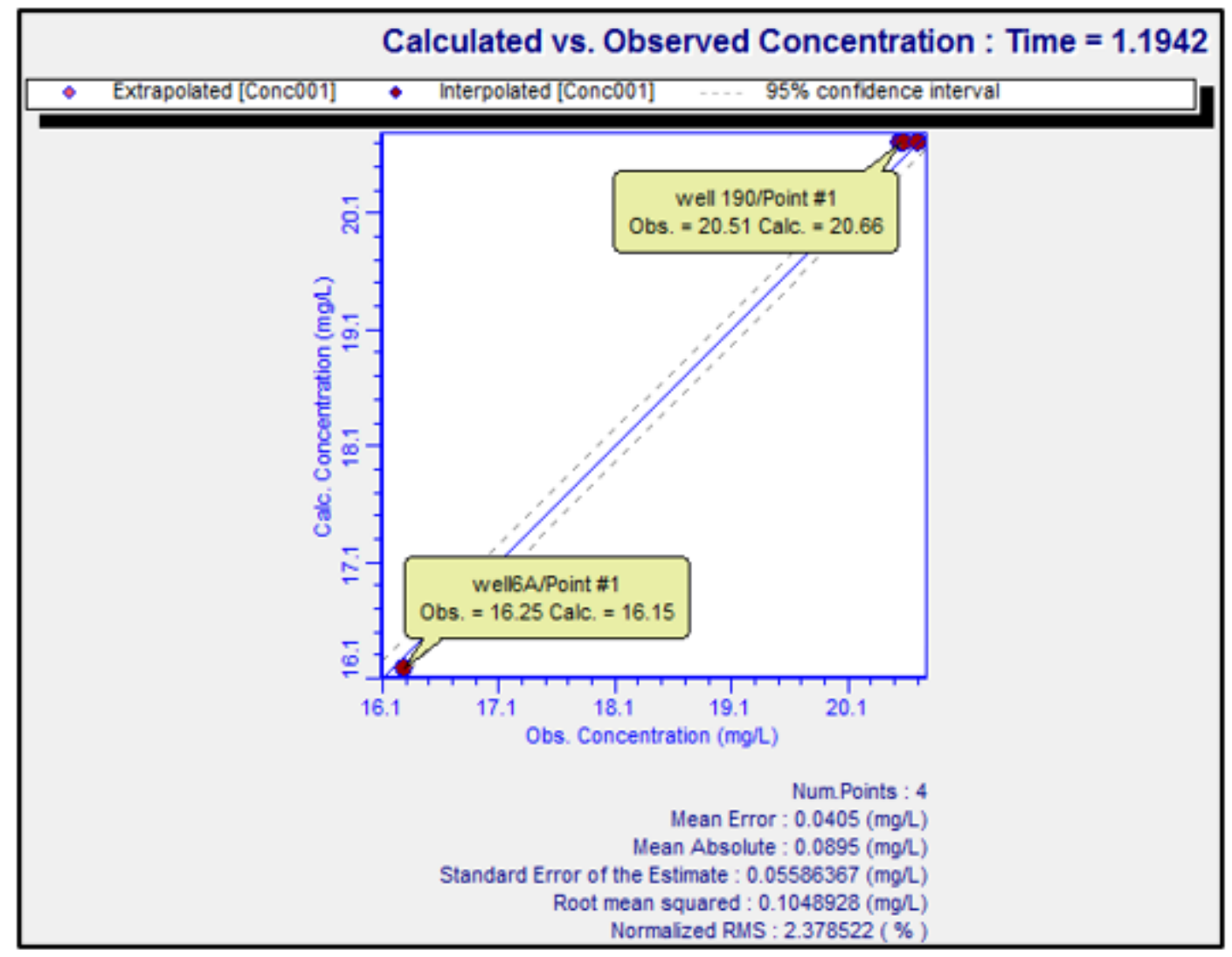

Figure 7

Model computed Vs observed concentration after calibration

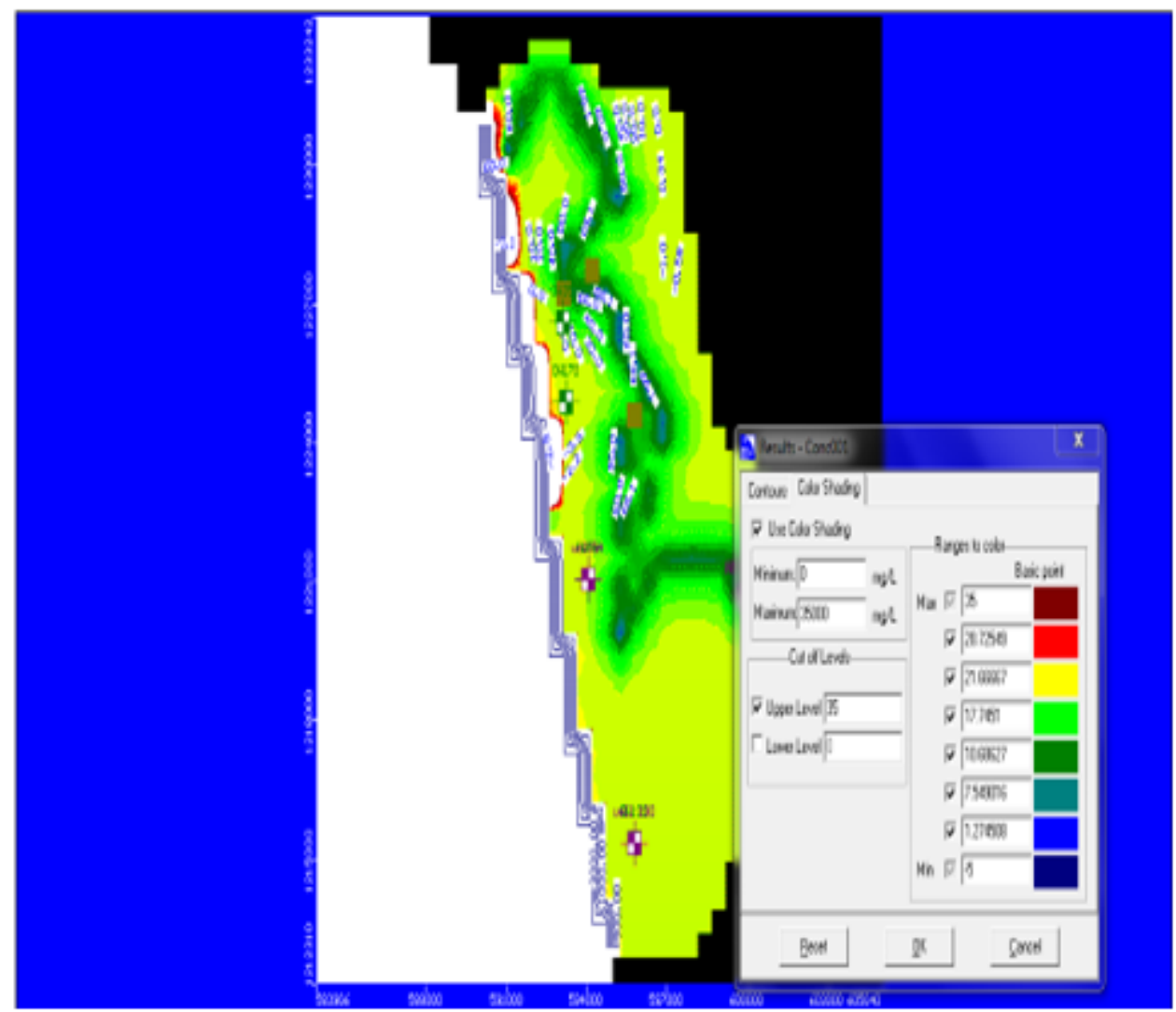


Figure 8

Chloride concentration contour map after calibration

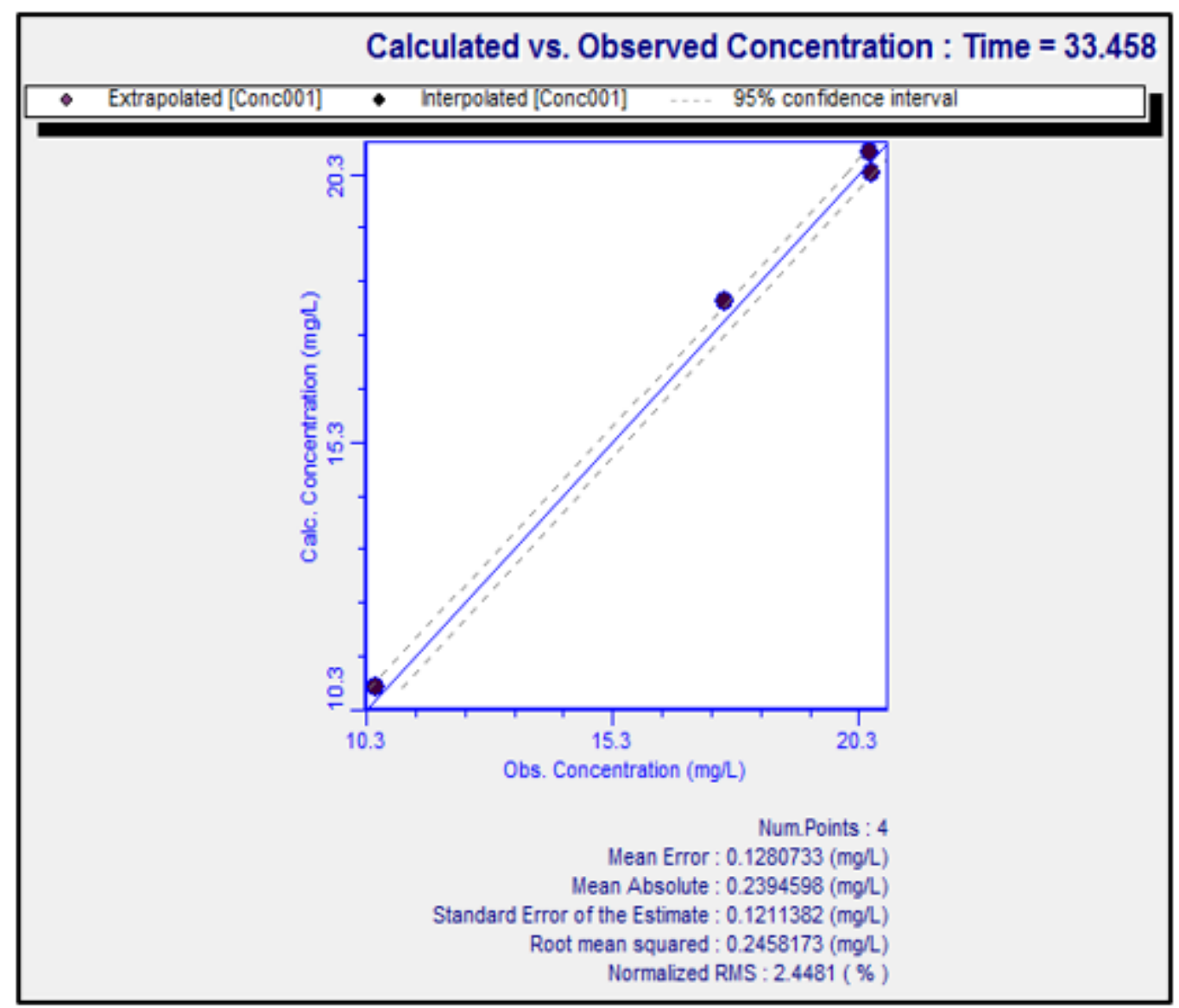

Figure 9

Model computed Vs observed concentration after validation 


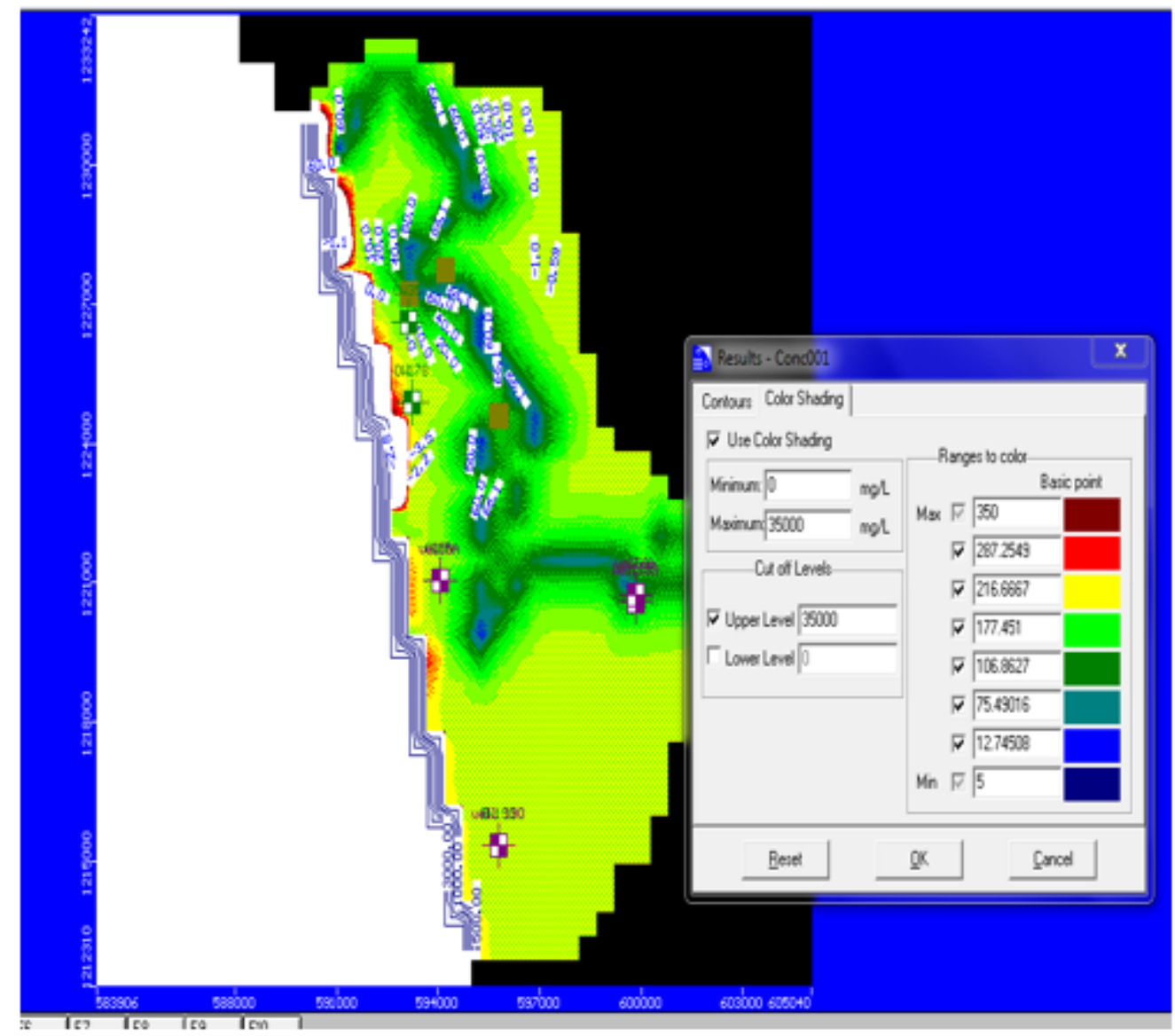

Figure 10

Chloride concentration contour map after validation
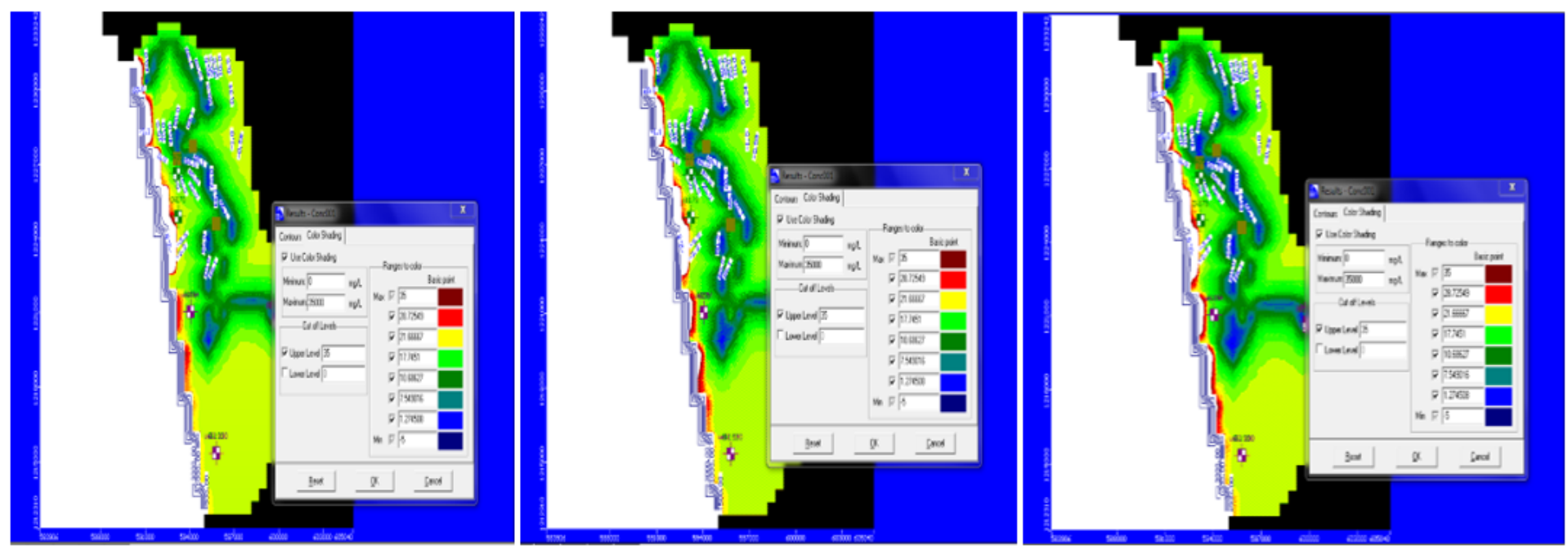

Figure 11

Predicted Chloride concentration contour map after increasing the pumping rate by 5,10 and 15 per cent

\section{Supplementary Files}


This is a list of supplementary files associated with this preprint. Click to download.

- Fig.48to51.docx 